Selcuk Journal of Agriculture and Food Sciences SJAFS

http://sjafs.selcuk.edu.tr/sjafs/index

(2020) 34 (1), 107-110

Research Article

e-ISSN: 2458-8377

DOI:10.15316/SJAFS.2020.202

\title{
Managing the Humic Acid Fertilizing of Chickpea and Protein Status**
}

\author{
Ali Kahraman ${ }^{1, *}$ \\ ${ }^{1}$ Selcuk University, Faculty of Agriculture, Department of Field Crops, Konya, Turkey
}

\begin{tabular}{l}
\hline ARTICLE INFO \\
\hline Article history: \\
Received date: 04.02 .2020 \\
Accepted date: 25.03 .2020 \\
\hline Edited by: \\
Ali SABIR; Selçuk University, Turkey \\
Reviewed by: \\
Tolga KARAKÖY; Sivas Cumhuriyet \\
University, Turkey \\
Furkan ÇOBAN; Atatürk University, \\
Turkey \\
\hline Keywords: \\
Cicer arietinum \\
Healthy nutrition \\
Food quality \\
Legumes \\
Sustainable agriculture
\end{tabular}

\begin{tabular}{l}
\hline ABSTRACT \\
Legumes are consumed for the nutrition of more than 2 billion people over the \\
world. As a legume, chickpea presents valuable nutritional components espe- \\
cially welded by higher protein and dietary fiber that is resistant to enzymatic \\
digestion in human body. Konya City is one of the most chickpea producers in \\
Turkey. In recent years, application of humic acid based fertilizer is increased \\
considerably. Aim of the study was determination of protein ratio and protein \\
yield of the field released chickpea seeds. A total of 4 humic acid doses (from \\
dose 1 to dose $4: 0,6,9$ and $12 \mathrm{~kg} \mathrm{da}^{-1}$ respectively) were applied by 2 equal \\
part (pre-sowing and pre-flowering periods) to the "Çagatay" chickpea variety \\
in Konya ecology. Field trial was set up by randomized blocks design with 3 \\
replications. According to results, protein ratio was detected between $20.56 \%$ \\
(dose 4 ) and $25.89 \%$ (dose 3 ) while protein yield (kg da ${ }^{-1}$ ) was ranged from \\
39.77 (dose 1 ) to 63.56 (dose 3 ) values. In the study, 9 kg da ${ }^{-1}$ humic acid \\
application presented the highest values for protein ratio and protein yield. On \\
the other hand, change in humic acid doses resulted from variable values. Deep \\
and long terms studies should evaluate more stable and trustable results to \\
decide optimum fertilizing for desired protein statues and sustainable agricul- \\
tural systems.
\end{tabular}

\section{Introduction}

Nutrition means a behavior for the purposes that; protection of health, growing and development, increasing of life quality and required for the body using sufficient levels of nutritional components by accurate timing and consciously (Viola et al., 2016). Human being provides the nutritional needs of animal and plant based food sources. Nutrition should be balanced and healthy. Growing food sources is easier on plants compared by animals welded by climatic factors, providing, transporting, storage, processing, etc. components. Therefore, plant based food sources are more common than animal based types and cheaper (Topalak and Ceyhan 2015; Kahraman 2017; Kafadar et al., 2019). According to the long term data of FAO (Anonymous 2019), although legumes take second place in the production of field crops, consumption by per person is quite low. Additionally, chickpea is the most produced legume in Turkey.

Legumes are the second family following to cereals over the world production. As a legume, chickpea (Cicer arietinum L.) is a commonly consumed legume crop in the world and Turkey as well (Anonymous

\footnotetext{
*Corresponding author email: kahramanali@selcuk.edu.tr

** Short communication
}

2019). Seeds of chickpea contain $38-73 \%$ carbohydrate, $16-31 \%$ protein, $2-9 \%$ cellulose, $2-7 \%$ oil, 2$11 \%$ ash (Encan et al 2005). There are various types of chickpea consumption in the world (Attia et al 1994) such as; directly cooking, coffee, varied fermented foods, frying, appetizer (S1k1l1 2003), "leblebi" a kind of cookies and animal feeding (Kara 1996). Additionally, chickpea seeds include non-polymeric starch components which are an important healthy food source while most of the ingredients are formed by cellulose, hemi-cellulose and pectin. The mentioned contents are associated with prevention of some important diseases such as hearth, diabetes, obesity, some of the cancer types, decreasing of blood cholesterol, normalization of glucose and insulin ratio (Kahraman 2017).

Increasing to yield and quality in plant production strictly related to soil characteristics. One of the most important factors for soil yield is; reaction $(\mathrm{pH})$ that is effecting availability of plant nutrition elements. Absorption of the soil elements by plants and soil microorganism activity is optimum on pH; 6-7 levels (Özbek 1973). Soil humic matters act as directly or indirectly on plant nutrition. Indirect effects are; water keeping, drainage and ventilation, improvement of soil physical features, changing the availability of soil minerals and absorption by roots. Humic matters create water soluble forms of metallic hydroxide by metallic ions and, controlling to many of those elements. Direct effects 
are; development of root, effecting of plant element metabolism in addition to fertilization causes to various prominent characteristics and mechanisms on plants (Lobartini et al 1997; Bozoglu et al 2007; Jankowski et al 2015; Toklu et al 2017; Sar1 et al 2018).

Using organic fertilizers is an important component for sustainability systems in agricultural production. Humic acid is one of the most used fertilizers over the world. On the other hand, chickpea acts on suspending of agricultural sustainability welded by symbiotic nitrogen fixation mechanism, root system, etc. main features as a legume crop.

As one of the most chickpea producer, Konya City is selected as a location for the present research. Chickpea variety called "Çăgatay" is commonly preferred by farmers. Using of humic acid based fertilizers is common in the region as well. So, various doses of humic acid applied to Çağatay chickpea variety in field conditions. The ratio of seed protein and protein yield is evaluated in the present manuscript.

\section{Materials and Methods}

In this paper, the unit dedicated as " $\mathbf{d a}^{\mathbf{- 1}}$ " equal to $1000 \mathrm{~m}^{-2}$ and also equivalent to $0.1 \mathrm{ha}^{-1}$ surface area of soil.

The field trial was located in Sarnıç Village of Altınekin Town in Konya City-Turkey ecological conditions. A certified chickpea variety "Çağatay" was used as plant material. Sowing was realized by hand on $14^{\text {th }}$ March 2013. Densities of seeds were $45 \times 15 \mathrm{~cm}$ on 7 rows for each plot by $4 \mathrm{~m}$ length. Randomized blocks design was set up by 3 replications. A total of 4 humic acid doses consisted from 0.0 (control), 6.0, 9.0 and 12 $\mathrm{kg} \mathrm{da}^{-1}$ applied to soil by two equal parts as pre-sowing and pre-flowering periods.

Tillage of soil had $20 \mathrm{~cm}$ of depth following to cereal harvest on autumn season. A total of $15 \mathrm{~kg} \mathrm{da}^{-1}$ DAP fertilizer (18\% Nitrogen and $46 \%$ phosphorus content) was applied to soil before sowing. Hoeing was made by hand for 2 times and irrigation was realized sprinkler for 2 times as well. Harvest was made on $20^{\text {th }}$ July 2013 by side effects of $45 \mathrm{~cm}$ from both sides.

According to meteorological data for long terms in Konya from March to July are reported as following: average temperature is $15.26^{\circ} \mathrm{C}$, total precipitation is $26.80 \mathrm{~mm}$ (Anonymous, 2016). characteristics of the trial soil presented a clay loam structure $(57.20 \%$ saturation) for depth of $0-20 \mathrm{~cm}$, good level of organic matter $(3.08 \%)$, slightly alkali $(\mathrm{pH}: 7.87)$, saltless ( $0.04 \%$ total salt), over limy ( $15.90 \%$ for lime), higher content of potassium $\left(216.67 \mathrm{~kg} \mathrm{da}^{-1}\right)$, very high content of phosphorus (17.97 $\left.\mathrm{kg} \mathrm{da}^{-1}\right)$.

Protein analyzes in seeds was realized by Kjeldahl method while protein yield was calculated by taking into account seed yield. Some of the results wholly independent from this paper were discussed in another report (Kahraman 2017) while present research was realized to the aim of protein ratio and protein yield of the field released Çağatay chickpea variety seeds.

\section{Results and Discussion}

Results of the presented study that was realized in Altınekin/Konya-Turkey ecological conditions by using "Çağatay" certified chickpea variety and application of 4 humic acid doses are summarized in this part.

In the present research, analysis of variance for protein ratio was statistically significant on the level of 5\% for protein ratio of the chickpea seeds. Protein ratio was detected; $20.56 \%$ on dose $4\left(12.0 \mathrm{~kg} \mathrm{da}^{-1}\right.$ humic acid application), $21.72 \%$ on control $\left(0.0 \mathrm{~kg} \mathrm{da}^{-1}\right.$ humic acid application - dose 1), $22.20 \%$ on dose $2(6.0 \mathrm{~kg}$ $\mathrm{da}^{-1}$ humic acid application) and $25.88 \%$ on dose 3 (9.0 $\mathrm{kg} \mathrm{da}^{-1}$ humic acid application), respectively. Results of the present research about protein ratio of the Çağatay chickpea seed showed that; overdose of humic acid application was not effective while recommended doses gave rise to an increase in the protein ratio of the chickpea seeds.

Protein ratio of chickpea seeds were reported in the previous researches as following; 22.53-23.69\% (Carillo et al 2000), 26.91\% (Brkic et al 2004), 16-31\% (Encan et al 2005), 20.60-26.70\% (Kaur and Singh 2004), $20.50-23.20 \%$ (Tayyar et al 2008), 21.00-24.00\% (Kopaç Kork 2009), 21.99-27.15\% (Doğan 2011), 18.83-20.43\% (Erdin and Kulaz 2014), 17.90-22.06\% (Bayrak and Onder 2017), while digestibility is 76$88 \%$ (Akçin 1988) besides biological value of egg is 100 and chickpea is 62 (Bayrak et al 2005). Slightly differences of the previous findings may be explained by; genetic structure, ecological conditions, cultural practices and especially by the humic acid application doses.

According to the results of this research, variance analysis was important for protein yield on 1\% significance level. Protein yield of the Çağatay chickpea variety showed a wide range depending on the humic acid application doses as following; $39.77 \mathrm{~kg} \mathrm{da}^{-1}$ on control $\left(0.0 \mathrm{~kg} \mathrm{da}^{-1}\right.$ humic acid application - dose 1$)$, $48.68 \mathrm{~kg} \mathrm{~kg} \mathrm{da}^{-1}$ on dose $4\left(12.0 \mathrm{~kg} \mathrm{da}^{-1}\right.$ humic acid application), $53.99 \mathrm{~kg} \mathrm{da}^{-1}$ on dose $2\left(6.0 \mathrm{~kg} \mathrm{da}^{-1}\right.$ humic acid application) and $63.56 \mathrm{~kg} \mathrm{da}^{-1}$ on dose $3(9.0 \mathrm{~kg}$ $\mathrm{da}^{-1}$ humic acid application). Present results introduced that; application of humic acid fertilizer was effective on protein yield of the chickpea that is limited by the usable values as obtaining the minimum value on control application and highest value on $9.0 \mathrm{~kg} \mathrm{da}^{-1}$ application. Former studies on chickpea showed the protein yield as; $24.68 \mathrm{~kg} \mathrm{da}^{-1}$ (Önder and Üçer 1999), 13.72$26.45 \mathrm{~kg} \mathrm{da}^{-1}$ (Bayrak and Onder 2017), 47.75-71.08 kg $\mathrm{da}^{-1}$ (Ceran and Önder 2016). The mentioned values are quite similar with data collected from the present study.

Previous research (Kıraç 2016) on peanut which was subjected to humic and fulvic acid (HFA) applications showed that; application of HFA was significantly effected by symbiotic nitrogen fixation while in- 
creased dose was adversely affected to several parameters. As a report of the study, the HFA application was positively affected by some of the investigated parameters and lower doses of HFA application were recommended. On the other hand, agronomic caharacteristics of plants are strictly related to genotype in addition to environmental factors (temperature and sunlight) and plant nutrition (Alam and Haider 2006). The content of dry matter is affected by photosynthetic activity, leaf area and leaf protein ratio (Ali et al 2004). On the other perspective, it is clear that fertilizing gives a lead to distinct changes in plant responses that are pointed out in another study as it stated in the following line. Phosphorus and zinc application to chickpea in Iran ecology proved that; plant height, number of main branch, 100 seed weight, seed yield, biological yield and protein concentration was significantly affected (Khourgamy and Farnia 2009). In another similar study in Iran (Mir et al 2014), phosphate and biologic biosuper phosphate application were also effected to 100 seed weight, seed yield and protein ratio.

\section{Conclusions}

Results of the present research showed remarkable effects such as; humic acid application level of overdose was not effective in the mean time recommended doses caused to increasing of the protein ratio.

According to the findings of the study, humic acid doses were effective and statistically significant on protein yield of Çağatay chickpea variety by the minimum value on control dose and highest value on $9.0 \mathrm{~kg}$ $\mathrm{da}^{-1}$ dose.

Application of several humic acid doses on chickpea variety Çağatay presented statistically significant statues on protein ratio and protein yield in the present research while $9 \mathrm{~kg} \mathrm{da}^{-1}$ humic acid application presented the highest values for protein ratio and protein yield as well. Deep and changed/modified studies on the subject which may be summarized by; various genotypes, ecologies, cultural practices, doses and application methods would be guided to more stable and trustable results.

\section{Acknowledgements}

Author of present research is very thankful to Sarraf Altınekinli/Konya-Turkey for admirable contributions from start to finish on the study.

\section{References}

Akçin A (1988). Yemeklik Dane Baklagiller. Selçuk Üniversitesi Yayınları No: 43, Konya (in Turkish).

Alam MZ, Haider SA (2006). Growth attributes of barley (Hordeum vulgare L.) cultivars in relation to different doses of nitrogen fertilizer. Journal of Life and Earth Sciences 1 (2): 77-82.

Ali H, Khan MA, Randhawa SA (2004). Interactive effect of seed inoculation and phosphorus applica- tion on growth and yield of chickpea (Cicer arietinum L.). International Journal of Agriculture \& Biology 6 (1): 110-112.

Anoymous (2016). data.org/location/497828/ 20.02.2016).

Anonymous (2019). Food and Agriculture Organisation, http://www.fao.org/faostat/en/ (Access date: 16.12.2019).

Attia RS, El-Tabey MA, Aman ME, Hamza MA (1994). Effect of cooking and decortication on the physical properties, the chemical composition, and nutritive value of chickpea (Cicer arietinum L. ). Food Chemistry 50: 125-131.

Bayrak H, Önder M, Gezgin S (2005). Effects on yield and some yield components of boron application in chickpea (Cicer arietinum L. ) varieties. Selcuk University Journal of Faculty of Agriculture 19 (35): 66-74.

Bayrak H, Önder M (2017). Determination of agricultural, technological and nutritional characteristics of local populations and varieties of chickpea (Cicer arietinum L.) cultivated in Konya ecological region. Journal of Central Research Institute for Field Crops 26 (Special Issue): 52-61. DOI: 10.21566/tarbitderg.359119.

Bozoglu H, Ozcelik H, Mut Z, Peksen E (2007). Response of chickpea (Cicer arietinum L.) to zinc and molybdenum fertilization. Bangladesh J Bot 36 (2): 145-149.

Brkic S, Milaković Z, Kristek A \& Antunović M (2004). Pea yield and its quality depending on inoculation, nitrogen and molybdenum fertilization. Plant Soil Environ. 50 (1): 39-45.

Carillo JM, Reyes-Moreno C, Armeimta-Rodello E, Carabez-Trejo A, Mora-Escobedo R (2000). Physicochemical and nutritional characteristics of extruded flours from fresh and hardened chickpeas (Cicer arietinum L). LWT - Food Science and Technology 33: 117-123.

Ceran F \& Önder M (2016). Determination of some agricultural characteristics on chickpea (Cicer arietinum L.) cultivars that are sown at different periods. MSc Thesis, Selcuk Journal of Agriculture and Food Science, 3 (1): 25-29.

Doğan Y (2011). Effects of various plant densities and sowing methods on yield and some yield components of chickpea (Cicer arietinum L.) cultivars in Van ecological conditions. PhD Thesis, The Graduate School Of Natural And Applied Science, Yüzüncü Y1l University, Van, Turkey.

Encan G, Kaya M, Çiftçi CY (2005). Nohutun Dünya ve Türkiye ekonomisindeki yeri. Süleyman Demirel Üniversitesi Fen Bilimleri Enstitüsü Dergisi 9 (1): 19-29 (in Turkish).

Erdin F, Kulaz H (2014). Van-Gevaş ekolojik koşullarında bazı nohut (Cicer arietinum L.) çeşitlerinin ikinci ürün olarak yetiştirilmesi. Turkish Journal of Agricultural and Natural Sciences 1: 910-914 (in Turkish). 
Jankowski KJ, Kijewski L, Krzebietke S, Budzynski WS (2015). The effect of sulphur fertilization on macronutrient concentrations in the post-harvest biomass of mustard. Plant Soil Environment 61 (6): 266-272.

Kafadar FN, Ozkan A, Can C, Kar Y, Mart D, Ceyhan C (2019). Genetic and biochemical properties of Cicer spp reveal distinction between wild and cultivated chickpea genotypes. Legume Research 42 (1): 1-9, doi: 10.18805/LR-395.

Kahraman A (2017). Effect of humic acid applications on the yield components in chickpea. Journal of Agricultural Faculty of Gaziosmanpasa University 34 (1): 218-222. ISSN: 1300-2910, E-ISSN: $2147-$ 8848 .

Kara K (1996). Tarla Bitkileri Ders Kitabı. Atatürk Üniversitesi Ziraat Fakültesi Yayınları No:191, 214-216 s, Erzurum (in Turkish).

Kaur M, Singh N (2004). Studies on functional, thermal and pasting properties of flours from different chickpea (Cicer arietinum L) cultivars. Food Chemistry 10: 1-5.

Khourgamy A, Farnia A (2009). Effect of phosphorus and zinc fertilization on yield components of chickpea cultivars. African Crop Sci. Conference Proc. 9: 205-208.

Kıraç G (2016). Effects of different humic-fulvic acid doses applications on biological nitrogen fixation under peanut vegetation. MSc Thesis, Süleyman Demirel University Graduate School of Natural and Applied Sciences Isparta, Turkey.

Kopaç Kork A (2009). Investigation on the effects of different processing methods on physical and chemical properties of chickpeas. MSc Thesis, The Graduate School Of Natural And Applied Science, Celal Bayar University, Manisa, Turkey.

Lobartini JC, Orioli GA, Tan KH (1997). Characteristics of soil humic acid fractions seperated by ultrafitration. Corn. SoiI Sci. Plant Anal. 28 (9 - 10): 787-796.

Mir H, Asilan KS, Daneshvar M, Mansorifar S (2014). The effects of chemical phosphorous and bio super phosphate bio fertilizer on qualitative and quantita- tive of the chick pea varieties in the dryaud condition. Spectrum: a. Journal of Multidisciplinary Research 3 (9): 235-248 (Special Issue on Multidisciplinary Studies).

Önder M, Üçer FB (1999). Konya ekolojik şartlarında bazı nohut çeşitlerinin ikinci ürün olarak yetiştirilmesi. Selçuk Üniversitesi Ziraat Fakültesi Dergisi 13 (18): 1-8 (in Turkish).

Özbek N (1973). Toprak verimliliği ve gübreler 1 . Toprak Verimliliği. Ankara Üniversitesi, Ziraat Fakültesi Yayınları: 525, Ders Kitabı: 170 (in Turkish).

Sarı H, Sarı D, Adak A, Çancı H, İkten C, Erler F, Yildırım T, Toker C, Kahraman A (2018). Assessment of leaf miner [Liriomyza cicerina Rond. (Diptera: Agromyzidae)] resistance in Cicer echinospermum P.H. Davis genotypes. Mediterranean Agricultural Sciences 31 (1): 71-75, doi: 10.29136/mediterranean.363722.

Sikılı ÖH (2003). Investigation of microbiological and flavour characteristics of chickpea sweet dough. $\mathrm{PhD}$ Thesis, Ege University Graduate School of Natural and Applied Sciences İzmir, Turkey (in Turkish).

Tayyar S, Egesel CÖ, Gül KM, Turhan H (2008). The effect of autumn and spring planting time on seed yield and protein content of chickpea genotypes. African Journal of Biotechnology 7 (11): 16551661.

Topalak C, Ceyhan E (2015). The effects of seed yield and some agricultural characters of different sowing dates on chickpea. Selcuk Journal of Agricultural Sciences 2 (2): 128-135.

Toklu F, Özkan H, Karaköy T, Coyne CJ (2017). Evaluation of advanced lentil lines for diversity in seed mineral concentration grain yield and yield components. Journal of Agricultural Sciences 23 (2017): 213-222.

Viola GCV, Bianchi F, Croce E, Ceretti E (2016). Are food labels effective as a means of health prevention? J Public Health Res 5 (3): 768. Doi: 10.4081/jphr.2016.768. 